\title{
Creatine Kinase Elevation during Antithyroid Treatment of a Patient with Graves' Disease: A Case Report and Review of Literature
}

Authors

Affiliations

Key words

- thyroid

- Graves' disease

- antibodies

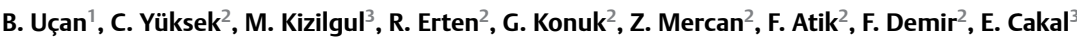

Affiliation addresses are listed at the end of the article

\section{Abstract \\ $\nabla$}

Thionamides (methimazole and propylthiouracil), which have been used in the treatment of graves' disease since 1940, inhibit the organification of iodine and coupling of iodotyrosines, thus blocking the synthesis of hormones. Myalgia is a rare side effect of these drugs. CK is the muscle specific kinase. The measurement of serum concentration of CK is useful to estimate the muscles' breakdown. We present a young male patient with Graves' disease who had abnormal increase of CK level during treatment with methimazole

\section{Introduction}

Graves' disease is characterized by excessive production of hormones by the diffusely enlarged thyroid gland as a result of thyroid-stimulating antibodies, which bind to and activate the thyrotropin receptor on thyroid cells. Thionamides (methimazole and propylthiouracil), which are used in the treatment of graves' disease, inhibit the organification of iodine and coupling of iodotyrosines, thus blocking the synthesis of hormones [1].

Minor side effects of thionamides are pruritis, cutaneous rash, urticaria, fever, arthralgia, nausea, sickness and olfaction disorders, and occur in $1-5 \%$ of patients. Minor side efects can resolve spontaneously; in case of persistence, the administered thionamide can be replaced by another available drug. Major side effects are agranulocytosis, hepatotoxicity, aplastic anemia and vasculitis, and occur in approximately $0.2-0.5 \%$ of the cases [2]. Myalgia is a rare side effect these drugs. We present a case of creatinine kinase elevation shortly after initiating metimazole, continued after switching to propylthioracil (PTU) and resolved with dose reduction.
(MMI). He experienced myalgia and elevated CK level 1 month after initiation of MMI. In the beginning of the myalgia, his free $\mathrm{T} 4$ level decreased to normal range. After dose reduction of MMI, CK level decreased and his symptoms were resolved. Although the mechanisms for this effect are not yet clear, it is thought that rapid decrease in thyroid hormone by antithyroid treatment in susceptible patients with graves' disease can be the cause of CK elevation. Measuring CK level in Graves disease patients presented with myalgia during treatment with antithyroid drugs would be a useful diagnostic tool.

\section{Case Presentation}

A 32 year old male patient who has been previously healthy, on no medications, presented for palpitation, hand tremors, easy fatigability and $14 \mathrm{~kg}$ weight loss during last 2 months. His serum TSH level was $<0.005 \mu \mathrm{IU} / \mathrm{mL}$ (normal range (NR): $0.27-4.2 \mu \mathrm{IU} / \mathrm{mL}$ ), free T3 (FT3) level was $16.53 \mathrm{pg} / \mathrm{dL}$ (NR: $2.6-4.8 \mathrm{pg} / \mathrm{dL}$ ), free T4 (FT4) level was $3.74 \mathrm{ng} / \mathrm{dL}(0.93-1.7 \mathrm{ng} / \mathrm{dL})$ and creatine kinase (CK) was 54U/L. Serum anti-thyroid peroxidase antibody was $132 \mathrm{IU} / \mathrm{mL}$ (NR: 0-34 IU/ $\mathrm{mL}$ ), anti thyroglobulin antibody was $772 \mathrm{IU} / \mathrm{mL}$ (NR: 0-115IU/mL), thyroid stimulating immunglobulin (TSI) was 32.72 U/L (NR: 0-14U/L). An ultrasonogram of thyroid gland demonstrated decreased echogenicity and pseudonodular appearance and, doppler ultrasonogram revealed enhanced vascularization. The 24 -h radioactive iodine uptake test as determined by a ${ }^{131}$ I thyroid scan was $48 \%$ (NR: 25-40). He was started on methimazole $20 \mathrm{mg} /$ day and propranolol $40 \mathrm{mg} /$ day. One week later his methimazole dose was decreased to $10 \mathrm{mg} /$ day due to a decrease in neutrofil count. His neutropenia was resolved after dose reduction. One month later he began to 
experience weakness, severe muscle cramps and myalgia. CK determination was $3775 \mathrm{U} / \mathrm{L}$ (NR: 30-200U/L) and his TSH level was $0.219 \mu \mathrm{IU} / \mathrm{mL}$, FT4 level was $0.94 \mathrm{ng} / \mathrm{mL}$, Ca level was $9.1 \mathrm{mg} /$ dL (NR: $8.6-10.4 \mathrm{mg} / \mathrm{dL}$ ), K level was $4.2 \mathrm{mEq} / \mathrm{L}$ (3.5-5.5 mEq/L), $\mathrm{Mg}$ level was $2.06 \mathrm{mg} / \mathrm{dL}(1.8-2.6 \mathrm{mg} / \mathrm{dL})$. All other labaratory findings were normal ( $\bullet$ Table 1 ). An electromyography examination was normal. His methimazole (MMI) dose was tapered to $5 \mathrm{mg} /$ day. 4 days later his symptoms resolved and his CK level reduced to $704 \mathrm{U} / \mathrm{L}$ but still remained elevated. Then MMI treatment was switched to propylthiouracil (PTU) $100 \mathrm{mg} /$ day. He still noticed cramps and myalgia 10 days after beginning of PTU therapy, at which point the serum TSH was $1.78 \mu \mathrm{IU} / \mathrm{mL}$, FT4 was $0.937 \mathrm{ng} / \mathrm{mL}$ and serum CK was $651 \mathrm{U} / \mathrm{L}$. All other labaratory findings were normal. PTU therapy was stopped and MMI $2.5 \mathrm{mg} /$ day started. One month later, his symptoms resolved and serum CK gradually normalized. Now, the patient is clinically stable on MMI $2.5 \mathrm{mg} /$ day therapy.

\section{Discussion}

$\nabla$

One of the frequently used medications for graves' disease is MMI. Common side effects of MMI include agrunulocytosis, skin rash and arthralgia, and the incidence of myalgia is very rare. CK is the muscle specific kinase. The measurement of serum concentration of CK is useful to estimate the muscles' breakdown. Our patient was in subclinical hyperthyroidism at the time of CK elevation. Other causes $[3,4]$ of CK elevation such as hypothyroidism, excessive physical exercise, neuromuscular disorders, myocardial infarction, stroke, epileptic seizures, repeated intramuscular injection, high fever, travma, statin treatment, hypocalcemia and alkalosis were unlikely in our patient. Thyrotoxic myopathy, usually involves proximal muscles of extremities, is painless and do not cause CK elevation [5]. Our patient had dramatically elevated $\mathrm{CK}$, thus making this diagnosis unlikely.

There are a number of case reports about antithyroid drug induced CK elevation in the literature. Shergy WJ et al. reported a case of a patient with polymyositis and high CK levels after PTU treatment for hyperthyroidism but the authors failed to distinguish if the elevation CK was related to drug effect of PTU or polymyositis. The patients symptoms resolved after withdrawal of PTU and treatment with prednisone and metotrexate [2]. Suzuki et al. reported 4 cases of adult patients with Graves' disease and an abnormal increase in serum CK concentrations during treatment with thionamides. The serum levels of CK were decreased after the reduction of the dose of MMI and adding levothyroxine to the treatment. The authors propounded that the rapid reduction in thyroid hormone causes a local hypothyroid state within the muscle tissue, which may have contributed to the CK elevations and they suggested that hasty correction of thyrotoxicosis should be avoided in susceptible patients, unless thyrotoxic conditions are critical such as cardiac failure or thyrotoxic crisis. They also mentioned that the direct effect of the agents to muscle or immunsuppresive action of drugs may have a role in thionamide induced CK elevation [6]. Mizuno described 2 cases of increases in serum CK concentrations in children undergoing treatment of Graves' disease with antithyroid medications. Both patients were euthyroid at the time of CK elevation. Authors speculated that the acute decrease of thyroid hormones in tissues following a state of chronic hyperthyroidism may result in relative hypothyroid states and subsequent alterations in CK concentrations as Suzuki et al. mentioned before [7]. Khalil et al. reported a case of MMI-induced myositis that resolved after withdrawal of the offending drug [8]. ChiehHua Lu described 2 cases presented with complaints of myalgia and muscle cramps, and serum CK elevation a few weeks after initiation of antithyroid treatment. The patients were in subclinical hyperthyroidism at the time of CK elevation. The authors propounded that acute decrease of thyroid hormones or blocking of the actions of deidinase may play a role in CK elevation [9]. $\mathrm{Kim} \mathrm{H}$ et al. reported a 13 year old patient with Graves disease who developed myalgia and elevated CK level after MMI treatment. After decrease in MMI dose and adding levothyroxine, her CK level reduced to normal range and her myalgia was resolved. They speculated that CK elevation could be a direct influence of antithyroid medications on muscle or a rapid decline in thyroid hormone level [10]. Ito $\mathrm{T}$ et al. reported a case with CK elevation during treatment with antithyroid drug. Adding levothyroxine to the treatment regimen was effective in their patient [11].

According to Suzuki et al., a rapid reduction of thyroid hormones regardless of mechanism is the cause of muscle symptoms and elevation of serum CK concentrations. This hypothesis is sug-

Table 1 Labaratory values of the patient.

\begin{tabular}{|c|c|c|c|c|c|}
\hline Labaratory tests & $\begin{array}{l}\text { At diagnosis of } \\
\text { hyperthyroidism }\end{array}$ & $\begin{array}{l}1 \text { month after starting } \\
\text { methimazole }(10 \mathrm{mg} / \mathrm{d})\end{array}$ & $\begin{array}{l}1 \text { week after tapering } \\
\text { the dose of methimazole } \\
(5 \mathrm{mg} / \mathrm{d})\end{array}$ & $\begin{array}{l}10 \text { days later methima- } \\
\text { zole switching to PTU } \\
100 \mathrm{mg} / \mathrm{d}\end{array}$ & $\begin{array}{l}1 \text { month after methi- } \\
\text { mazole } 2.5 \mathrm{mg} / \mathrm{d}\end{array}$ \\
\hline 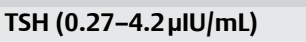 & $<0.005$ & 0.219 & 0.672 & 1.78 & 1.749 \\
\hline FT3 (2.6-4.8 pg/dL) & 16.53 & 2.83 & 2.78 & 3.18 & 3.03 \\
\hline FT4 (0.93-1.7ng/dL) & 3.74 & 0.94 & 0.951 & 0.937 & 1.06 \\
\hline $\begin{array}{l}\text { Anti thyroglobulin } \\
\text { (0-115 U/mL) }\end{array}$ & 772 & - & - & - & - \\
\hline Anti TPO (0-34 IU/mL) & 132 & - & - & - & - \\
\hline TSI (0-14U/L) & 32.72 & - & - & - & - \\
\hline CK (30-200 U/L) & 54 & 3775 & 704 & 651 & 106 \\
\hline AST (5-34U/L) & 15 & 30 & 20 & 18 & 19 \\
\hline ALT (0-55U/L) & 19 & 16 & 16 & 12 & 18 \\
\hline LDH (125-220U/L) & - & - & 199 & 181 & 310 \\
\hline WBC $(4000-1000)$ & 5700 & 4800 & 5800 & 5900 & 6100 \\
\hline Neurofil count (500-1500) & 3300 & 2600 & 3000 & 3100 & 3580 \\
\hline
\end{tabular}

AST, aspartate transaminase; ALT, alanine aminotransferase; TSI, thyroid stimulating immunglobulin; Anti TG, anti thyroglobulin antibody; Anti TPO, anti-thyroid peroxidase antibody; WBC, white blood cell count; CK, creatine kinase 
gested by Hernán Martínez J et al. They mentioned that thyroid hormone is important for the expression of fast myofibrillar proteins in the muscle. In hypothyroidism the expression of these proteins are deficient and there is an increase accumulation of slow myofibrillar proteins. They reported a case of rapid or abrupt decrease in thyroid hormones caused by radioiodine therapy after prolonged hyperthyroidism can lead to local hypothyroid state within the muscle tissue, resulting in CK elevation and hypothyroid myopathy [12]. As an opposing view, if this hypothesis is true CK elevation must be seen in more people with Graves' disease treated with thionamides. In light of these information, it can put forward that abrupt decrease in thyroid hormone level with thionamides in susceptible host may have a role in CK elevation.

Serum creatine kinase is often increased and correlates with the severity of hypothyroidism [13]. Our patient had CK elevation without hypothyroidsm during treatment. At the time of CK elevation his FT4 level was at the lower limit of normal so this situation can suggest the hypothesis described above.

In conclusion, CK elevation with complaints of myalgia and cramps can be seen as a rare side effect of antityroid drug treatment in patients with hyperthyroidism due to Graves' disease and it may be diminished with antithyroid dose reduction. These complications can be an indication for radioiodine therapy in Graves disease patients treated with antithyroid drugs. Although the mechanisms for this effect are not yet clear, it is thought that rapid decrease in thyroid hormone by antithyroid treatment in susceptible patients with graves' disease can be the cause of CK elevation. Measuring CK level in Graves disease patients presented with myalgia during treatment with antithyroid drugs would be a useful diagnostic tool.

Disclosure statement: The authors have nothing to disclose.

\section{References}

1 Marino M, Vitti P, Chiovato L. Graves' Disease. In: Jameson JL, De Groot LJ (eds.). Endocrinology: Adult and pediatric. $7^{\text {th }}$ edn. Philadelphia: Saunders, Elsevier; 2016: 1437-1464

2 Fumarola A, Di Fiore A, Dainelli M, Grani G, Calvanese A. Medical treatment of hyperthyroidism: state of the art. Exp Clin Endocrinol Diabetes 2010; 118: 678-684

3 Prelle A, Tancredi L, Sciacco M, Chiveri L, Comi GP, Battistel A. Retrospective study of a large population of patients with asymptomatic or minimally symptomatic raised serum creatine kinase levels. J Neurol 2002; 249: 305-311

4 Morandi L, Angelini C, Prelle A, Pini A, Grassi B, Bernardi G. High plasma creatine kinase: review of the literature and proposal for a diagnostic algorithm. Neurol Sci 2006; 27: 303-311

5 Shergy WJ, Caldwell DS. Polymyositis after propylthiouracil treatment for hyperthyroidism. Ann Rheum Dis 1988; 47: 340-343

6 Suzuki S, Ichikawa K, Nagai M, Mikoshiba M, Mori J, Kaneko A. Elevation of serum creatine kinase during treatment with antithyroid drugs in patients with hyperthyroidism due to Graves disease. A novel side effect of antithyroid drugs Arch Intem Med 1997; 157: 693-696

7 Mizuno H, Sugiyama Y, Nishi Y, Ueda N, Ohro Y, Togari H. Elevation of serum creatine kinase in response to medical treatment of Graves' disease in children. Acta Paediatr 2006; 95: 243-245

8 Bou Khalil R, Abou Salbi M, Sissi S, El Kara N, Azar E, Khoury M. Methimazole-induced myositis: a case report and review of the literature. Endocrinol Diabetes Metab Case Rep 2013; 2013: 130008

$9 \mathrm{Lu} \mathrm{CH}, \mathrm{Hsieh} \mathrm{CH}$. Elevation of creatine kinase during medical treatment of graves' disease. J Med Sci 2007; 27: 241-244

$10 \mathrm{Kim} \mathrm{H,} \mathrm{Kim} \mathrm{J,} \mathrm{Huh} \mathrm{R,} \mathrm{Cho} \mathrm{SY,} \mathrm{Jin} \mathrm{DK.} \mathrm{Elevation} \mathrm{of} \mathrm{serum} \mathrm{creatine} \mathrm{kinase}$ during methimazole treatment of Graves disease in a 13-year-old girl and a literature review of similar cases. Ann Pediatr Endocrinol Metab 2015; 20: 106-109

11 Ito T, Katahira M, Hanakita M, Suzuki M. A case of elevation of serum creatine kinase with antithyroid medications for Graves disease. J Endocrinol Metab 2012; 2: 244-247

12 Hernán Martínez J, Sánchez A, Torres $O$, Palermo C, Santiago $M$, Figueroa $C$. Abrupt onset of muscle dysfunction after treatment for Grave's disease: a case report. Bol Asoc Med P R 2014; 106: 40-42

13 Wilmar M. Wiersinga Hypothyroidism and Myxedema Coma. In: Jameson JL, De Groot LJ (eds.). Endocrinology: Adult and pediatric. $7^{\text {th }}$ edn. Philadelphia: Saunders, Elsevier; 2016: 1540-1556

\section{Affiliations}

Izzet Baysal Teaching and Research Hospital, Deparment of Endocrinology,

Abant Izzet Baysal University School of Medicine, Bolu, Turkey

${ }^{2}$ Izzet Baysal Teaching and Research Hospital, Deparment of Internal

Medicine, Abant Izzet Baysal University School of Medicine, Bolu, Turkey

Department of Endocrinology and Metabolism, Diskapi Teaching and

Research Hospital, Ankara, Turkey 